\title{
Asperger syndrome with concomitant anorexia nervosa or transgenerational transmission of trauma?
}

\author{
Zespół Aspergera z towarzyszącym jadłowstrętem psychicznym \\ czy transgeneracyjna transmisja traumy?
}

\author{
Department of Developmental Psychiatry, Psychotic and Geriatric Disorders, Medical University of Gdańsk, Gdańsk, Poland \\ Correspondence: Izabela Łucka, Department of Developmental Psychiatry, Psychotic and Geriatric Disorders, GUMed, Srebrniki 17, 80-282 Gdańsk, Poland, e-mail: izabelalucka@wp.pl
}

Klinika Psychiatrii Rozwojowej, Zaburzeń Psychotycznych i Wieku Podeszłego, Gdański Uniwersytet Medyczny, Gdańsk, Polska

Adres do korespondencji: Izabela Łucka, Klinika Psychiatrii Rozwojowej, Zaburzeń Psychotycznych iWieku Podeszłego GUMed, ul. Srebrniki 17, 80-282 Gdańsk, e-mail: izabelalucka@wp.pl

Abstract The identification criteria of autism spectrum disorders, based on symptoms presented by patients and difficulties reported by their carers, still raise controversies and doubts. Despite more and more precise diagnostic instruments, multiple dilemmas associated with establishing a proper diagnosis are still encountered in clinical practice. These mainly concern individuals with autism spectrum who are highly functional and able to compensate for or camouflage their deficits. It also happens that a behaviour of a given person confusingly resembles autism spectrum disorders, but its cause lies in problems linked with consequences of traumatic experiences of the posttraumatic stress nature which have been present for several generations. Moreover, the coexistence of both these mechanisms, i.e. neurobiological causes and disturbed relations resulting from trauma inheritance, cannot be excluded. The article discusses the process of psychotherapy in a patient who was allowed by her family system to seek specialist help only after the occurrence of severe clinical symptoms defined by a professional diagnosis. The woman belonged to a family generation that was able to recreate its dramatic history. This helped combine the cold intellectual message with profound feelings experienced by physically and emotionally harmed women, particularly during ethnic cleansing in the Polish Eastern Borderlands and repatriation.

Keywords: Asperger syndrome, eating disorders, transgenerational transmission of trauma

Streszczenie Kryteria identyfikacji zaburzeń ze spektrum autyzmu, bazujące na prezentowanych przez pacjentów symptomach i zgłaszanych przez opiekunów trudnościach, nadal budzą kontrowersje oraz wątpliwości. W codziennej praktyce klinicznej, mimo coraz precyzyjniejszych narzędzi diagnostycznych, napotykamy na wiele dylematów związanych z ustaleniem odpowiedniego rozpoznania. Dotyczy to zwłaszcza osób ze spektrum autyzmu wysoko funkcjonujących, potrafiących kompensować albo kamuflować swoje deficyty. Bywa i tak, że zachowanie danej osoby łudząco przypomina zaburzenia ze spektrum autyzmu, jednakże podłoża prezentowanych trudności należy szukać w problemach związanych z trwającymi od kilku pokoleń skutkami traumatycznych doświadczeń o charakterze stresu pourazowego. Nie można także wykluczyć współwystępowania obydwu mechanizmów - podłoża neurobiologicznego oraz zaburzeń w relacjach wynikających z dziedziczenia traumy. Praca omawia proces psychoterapii pacjentki, która dopiero po pojawieniu się ciężkich objawów klinicznych, zdefiniowanych diagnozą lekarską, zdołała uzyskać przyzwolenie systemu rodzinnego na poszukiwanie specjalistycznej pomocy. Kobieta przynależała do tego pokolenia w rodzinie, które mogło sobie pozwolić na odtworzenie dramatycznej historii z przeszłości. Dzięki temu udało się połączyć chłodny przekaz intelektualny z głębokimi uczuciami, których doświadczyły krzywdzone fizycznie i emocjonalnie kobiety, zwłaszcza podczas czystek etnicznych na Kresach Wschodnich oraz repatriacji.

Słowa kluczowe: zespół Aspergera, zaburzenia odżywiania, transgeneracyjna transmisja traumy 


\section{INTRODUCTION}

A sperger syndrome (AS) is one of pervasive developmental disorders, also referred to as autism spectrum disorder (ASD). The diagnostic criteria included in the classification of mental disorders of the American Psychiatric Association, called Diagnostic and Statistical Manual of Mental Disorders (DSM-IV), and in the International Statistical Classification of Diseases and Related Health Problems (ICD-10) are based on the occurrence of restricted and repetitive patterns of behaviour, verbal and non-verbal communication disorders as well as social competence deficits (American Psychiatric Association, 2010, DSM-5; Baron-Cohen, 2008, 2002). The latest diagnostic classification, i.e. DSM-5, underlines the need to present the above listed symptoms in early childhood, but their absence does not preclude an ASD diagnosis in later life. The ability to diagnose ASD together with other concomitant abnormalities, e.g. affective or eating disorders, is an equally important change introduced in DSM-5 (American Psychiatric Association, 2010, DSM-5). Heated discussions are raised especially by ASD being concomitant with the restricting type of anorexia nervosa. It is debated whether neuropsychological changes that start resembling ASD appear due to the debilitating course of anorexia nervosa, or whether eating disorders - often unrecognised until starvation - are triggered by autism spectrum (Koch et al., 2015; Treasure, 2013).

The ASD identification criteria, which are based on symptoms presented by patients and difficulties reported by their carers, still evoke discussions and raise controversies among experts. Despite more and more precise diagnostic instruments, multiple dilemmas associated with establishing a proper diagnosis are still encountered in clinical practice. These mainly concern individuals with ASD who are highly functional and able to compensate for or camouflage their deficits effectively. Proper diagnosis is often established late in these patients. It also happens that a given person's functioning confusingly resembles ASD, but its cause lies in problems linked with consequences of traumatic experiences of the posttraumatic stress nature which have been present for several generations. This mainly concerns more or less internalised mechanisms of a family functioning as a system, with its delegations, loyalty, and notes in the family's "account book" that records merits and debts to be paid. This legacy passed on from generation to generation shapes behaviour, affects life decisions, partner selection and relationships with relatives or friends. The expectation of "payment" distorts the structure of a family and roles performed in it, thereby leading to parentification of children and making their separation and individualisation harder.

This phenomenon was noticed in the 1950s by psychoanalysts who described the consequences of deprivation of early childhood experiences with the relationships with parents. An additional problem that makes it difficult to deal with the past is the need to conceal the suffered harm.

\section{WPROWADZENIE}

$\mathrm{Z}$ espół Aspergera (ZA) należy do całościowych zaburzeń rozwojowych, nazywanych także zaburzeniami ze spektrum autyzmu (autism spectrum disorder, ASD). Kryteria diagnostyczne zawarte w klasyfikacji zaburzeń psychicznych Amerykańskiego Towarzystwa Psychiatrycznego DSM-IV (Diagnostic and Statistical Manual of Mental Disorders, DSM-IV) oraz w Międzynarodowej Statystycznej Klasyfikacji Chorób i Problemów Zdrowotnych ICD-10 (International Statistical Classification of Diseases and Related Health Problems, ICD-10) bazują na występowaniu u pacjentów sztywnych, stereotypowych wzorców zachowania, nieprawidłowości w sferze komunikacji werbalnej oraz niewerbalnej, a także deficytów w zakresie kompetencji społecznych (American Psychiatric Association, 2010, DSM-5; Baron-Cohen, 2008, 2002). W nowej klasyfikacji diagnostycznej DSM-5 podkreśla się konieczność prezentowania wyżej wymienionych symptomów już we wczesnym dzieciństwie, ale ich brak nie wyklucza rozpoznania ASD w okresie późniejszym. Równie ważną zmianą wprowadzoną w DSM-5 jest możliwość diagnozowania ASD z innymi zaburzeniami współwystępującymi, na przykład z zaburzeniami afektywnymi czy zaburzeniami odżywiania (American Psychiatric Association, 2010, DSM-5). Zwłaszcza obserwowanie objawów ASD wraz z restrykcyjną formą jadłowstrętu psychicznego rodzi gorące dyskusje wokół stawianego pytania: czy to na skutek głębokiego wyniszczenia organizmu w przebiegu choroby głodowej następują takie zmiany w funkcjonowaniu neuropsychologicznym pacjentów, które zaczynają przypominać ASD, czy też bazą do rozwoju zaburzeń odżywiania były - często do czasu wygłodzenia nierozpoznane - zaburzenia ze spektrum autyzmu (Koch et al., 2015; Treasure, 2013)?

Kryteria identyfikacji ASD - bazujące na prezentowanych przez pacjentów symptomach i zgłaszanych przez opiekunów trudnościach - nadal budzą kontrowersje, wywołują dyskusje oraz wątpliwości wśród ekspertów. W codziennej praktyce klinicznej, mimo coraz precyzyjniejszych narzędzi diagnostycznych, napotykamy na wiele dylematów związanych $\mathrm{z}$ ustaleniem odpowiedniego rozpoznania. Dotyczy to zwłaszcza osób z ASD wysoko funkcjonujących, potrafiących skutecznie kompensować albo kamuflować swoje deficyty. Pacjenci tacy często bardzo późno otrzymują odpowiednie rozpoznanie. Bywa i tak, że funkcjonowanie danej osoby łudząco przypomina ASD, jednakże podłoża prezentowanych trudności należy szukać $\mathrm{w}$ problemach związanych $\mathrm{z}$ trwającymi od kilku pokoleń skutkami traumatycznych doświadczeń o charakterze stresu pourazowego. Dotyczy to zwłaszcza uwewnętrznionych (mniej lub bardziej świadomie) mechanizmów funkcjonowania rodziny jako systemu - z delegacjami, lojalnościami, przekazami wynikającymi z rodzinnej „księgi rachunkowej”, w której zapisywane są zasługi i długi do spłacenia. Owo dziedzictwo przechodzące z pokolenia na pokolenie kształtuje sposób zachowania, wpływa na podejmowane decyzje życiowe, 
The family as a system functions in a specific community and in a given socio-political context. After the Second World War in Poland, it was allowed to speak openly about crimes committed by Nazi Germany, but atrocities perpetrated by Russians or Ukrainians were, until recently, a taboo (Łucka and Nowak, 2014; Orwid, 2009; Prot et al., 2010; Pudlo et al., 2005; Wasilewska, 2012). The clinical material presented below, with the patient's consent, illustrates a difficult path of uncovering the transgenerational legacy and dealing with it. As it seems, this process is the only way to win back autonomy and regain health. It also helps rediscover one's own place in the genealogical tree, feel one's belonging and understand previously seemingly senseless aspects of the family functioning.

\section{DESCRIPTION OF THERAPEUTIC WORK}

Laura, a 19-year-old female patient, treated pharmacologically for profound depression, reported for psychotherapy due to an eating disorder identified as anorexia nervosa. She had previously been diagnosed with AS in a specialist centre for autistic patients.

The patient comes from a broken family. Her parents are highly educated, financially independent and live together in spite of divorce. The patient has a one-year younger brother and a 12-year-old sister.

Laura is highly intelligent, uses elaborate Polish language and lively modulates utterances. She combines facts with ease, draws right conclusions, boldly makes hypotheses and is characterised by high motivation for therapy. During meetings, the non-verbal contact is very good. She presents lively facial expressions and uses lots of affective interjections, adequate for uttered content. At the same time, in initial stages of the meetings, she verbally denied having any emotions. She had significant difficulty with naming feelings and realising that she was experiencing a variety of emotional states while taking about events important to her. She claimed not to have any feelings and said that she "did not understand feelings" as she did not experience any. At the next stage of the therapeutic work, she often expressed regret that she actually did have and experience various emotions, because they complicated her intellectual receipt of and contact with the world. She believed that it would have been best for her to have no feelings whatsoever and use only reason.

In the conversations, she frequently referred to her childhood. On the one hand, she recollected it as a wonderful and magical world, which appeared in stories of unusually creative entertainments with her brother. On the other hand, she viewed it as a time when she felt very lonely and not understood. As for her relationship with adults, she experienced immense helplessness and frustration combined with abrupt outbursts of aggression. The main issue was the relationship with her parents, in particular the mother who was unable to cope with anger and discomfort of the pa- wybory partnerów, relacje z bliskimi. Oczekiwanie „zapłaty" zaburza strukturę rodziny i pełnione w niej funkcje, prowadząc do parentyfikacji dzieci oraz utrudniając ich separację $\mathrm{i}$ indywiduację.

Zjawisko to już w latach 50. ubiegłego wieku zauważyli psychoanalitycy opisujący skutki deprywacji wczesnodziecięcych doświadczeń w relacji z rodzicami. Dodatkowym problemem utrudniającym rozliczenie z przeszłością jest konieczność utrzymywania przeżytych krzywd w tajemnicy. Rodzina jako system funkcjonuje w konkretnym społeczeństwie, w określonym kontekście społeczno-politycznym. W Polsce po II wojnie światowej wolno było mówić o zbrodniach popełnionych przez nazistowskie Niemcy, jednak okrucieństwa dokonane przez Rosjan czy Ukraińców stanowiły do niedawna temat tabu (Łucka i Nowak, 2014; Orwid, 2009; Prot et al., 2010; Pudlo et al., 2005; Wasilewska, 2012). Poniżej przedstawiony - za zgodą pacjentki - materiał kliniczny ilustruje trudną drogę odkrywania transgeneracyjnego dziedzictwa i rozliczania się z nim. Proces ten jest równocześnie jedynym, jak się wydaje, sposobem na wywalczenie autonomii i odzyskanie zdrowia. Pozwala też odnaleźć swoje miejsce w drzewie genealogicznym, poczuć swoją przynależność i zrozumieć to, co dotychczas $w$ funkcjonowaniu rodziny wydawało się nie mieć sensu.

\section{OPIS PRACY TERAPEUTYCZNEJ}

Pacjentka Laura, lat 19, leczona farmakologicznie z powodu głębokiej depresji, zgłosiła się na psychoterapię z powodu zaburzeń odżywiania o charakterze jadłowstrętu psychicznego. Została ostatnio zdiagnozowana w specjalistycznym ośrodku dla osób autystycznych, gdzie rozpoznano u niej ZA. Pochodzi z rodziny rozbitej. Rodzice są wysoko wykształceni, niezależni finansowo, mimo rozwodu nadal mieszkają razem. Pacjentka ma młodszego o rok brata i dwunastoletnią siostrę.

Kobieta jest osobą wybitnie inteligentną, posługuje się piękną polszczyzną, żywo modulując wypowiedzi, z łatwością łączy fakty, wyciąga trafne wnioski, śmiało stawia hipotezy, cechuje się dużą motywacją do pracy terapeutycznej. Podczas spotkań pozostaje w bardzo dobrym kontakcie niewerbalnym, prezentuje żywą mimikę, mówi z dużym przydźwiękiem afektywnym, adekwatnym do wypowiadanych treści. Jednocześnie - na początkowym etapie spotkań słownie zaprzeczała temu, że doznaje jakichkolwiek emocji. Miała duży problem z nazywaniem uczuć oraz uświadomieniem sobie tego, że podczas opowiadania o ważnych dla siebie wydarzeniach doświadcza różnorodnych stanów emocjonalnych. Twierdziła, że nie ma uczuć, że „nie rozumie uczuć”, bo ich nie doświadcza. Na następnym etapie pracy terapeutycznej często wyrażała żal, że jednak odczuwa i przeżywa różne emocje, bo to komplikuje jej intelektualny odbiór świata i kontakt z nim. Uważała, że najlepiej byłoby, gdyby uczuć jednak nie miała, a kierowała się jedynie rozsądkiem. 
could do and what the girl needed to calm dawn. This attitude only potentiated the girl's frustration and exacerbated her aggressive behaviour. The patient also mentioned the relationships with other adults - her parents' friends - who were afraid of her, called her a bad child, hid from her and ran away as though she was the "devil incarnate." Another figure that was important for the patient was her grandmother. She was a stern, disciplined and educated woman who put immense attention to the "right" behaviour in every situation. At that time, she was the central figure of the family. She was very demanding and constantly dissatisfied with accomplishments (even prominent) of each family member, particularly of her daughter, i.e. the patient's mother. The grandmother often spitefully commented, criticised and downgraded any action of her daughter. Afterwards as an apology - she would send her homemade meals, and in them notes full of further dissatisfaction. No one wanted to eat these meals, but the patient's mother was afraid to send them back or to throw them out. This generated further tension at the patient's home. The grandmother, who was too skinny in the past, served meals to a neatly laid table, but did not sit at it herself and did not eat meals together with the family. Instead, she would ask: "Is the food eatable?". At the early stage of treatment, the patient did not prepare any meals for herself. Her mother had to think of various recipes and serve meals in a fancy and inventive way in order to feed her daughter. Her father performed similar tasks.

At this stage, the patient identified herself with the emotionally cold, overambitious grandmother who stimulated her to constant work or study, and forbade rest or pleasures, which were understood as symptoms of laziness and weakness. The mother's efforts and care for her daughter's health and well-being were neglected by both the grandmother and the patient. The mother's actions were deemed exaggerated despite the patient's evident low body weight and deep exacerbation of depression. The patient also started recalling her trip to India where she was a guest of a traditional Hindi family whose members were emotionally close to one another and eagerly spent their free time together, and where meals were an integral part of this. The patient stated that "she liked eating everything there" and she even gained some weight. Increased eating disorders and depression developed after returning home and were additionally made worse by the death of the grandmother's sister, which had a strong impact on the patient. We began to create a genogram of the patient's family, focussing mainly on the mother's clan with which the patient identified herself. The family comes from today's Ukraine. The patient's great grandmother was a resourceful woman, fully in charge of her household. For unknown - perhaps financial - reasons she decided to marry her only daughter to a violent and unstable man, in spite of her husband's and sons' opinions. The brothers tried to dissuade the suitor by making him believe that their sister was disabled and blind, only to protect her from this marriage.
W rozmowach chętnie nawiązywała do swojego dzieciństwa. Wspominała je $z$ jednej strony jako świat cudowny i magiczny, pojawiający się w opowieściach związanych $\mathrm{z}$ niezwykle kreatywnymi zabawami z bratem, $\mathrm{z}$ drugiej jednak - jako czas, w którym czuła się bardzo samotnym, przez nikogo niezrozumianym dzieckiem. W kontaktach $\mathrm{z}$ dorosłymi doświadczała ogromnej bezradności i frustracji połączonych z gwałtownymi wybuchami agresji. Na plan pierwszy wysuwały się relacje z rodzicami, szczególnie z matką, która nie potrafiła sobie poradzić z przejawami złości i dyskomfortu pacjentki. Często bezradnie pytała córkę, co ma zrobić, czego dziecko potrzebuje, żeby mogło się wyciszyć i uspokoić. Taka postawa potęgowała jeszcze frustrację dziewczynki i nasilała jej agresywne zachowania. Pacjentka wspominała także reakcje innych dorosłych - $\mathrm{z}$ kręgu znajomych rodziny - którzy bali się jej, nazywali ją złym dzieckiem, chowali się przed nią, uciekali jak „od zła wcielonego”. Kolejną ważną dla kobiety figurą była babcia - surowa, zdyscyplinowana, wykształcona osoba, przykładająca dużą wagę do „odpowiedniego" zachowania w każdej sytuacji. W tamtym czasie stanowiła centralną postać rodziny. Była to osoba bardzo wymagająca i nieustannie niezadowolona $\mathrm{z}$ osiągnięć nawet wybitnych - wszystkich domowników, a zwłaszcza swojej córki, czyli matki pacjentki. Babcia często złośliwie komentowała, krytykowała i deprecjonowała wszelkie jej poczynania. Następnie - jakby na przeprosiny - przysyłała jej zrobione własnoręcznie potrawy, a w nich pełne dalszego niezadowolenia liściki. Posiłków tych nikt nie chciał zjadać, ale mama obawiała się je odesłać lub wyrzucić. Generowało to więc kolejne napięcia $w$ domu pacjentki. Babcia - w przeszłości nazbyt szczupła - podawała do starannie nakrytego stołu, ale sama przy nim nie siadała, nie jadła wspólnych posiłków, często za to pytała: „Czy jedzenie jest zjadliwe?”. Pacjentka w początkowej fazie leczenia nie przygotowywała sobie żadnego posiłku - mama musiała wymyślać potrawy i podawać je w atrakcyjny, pomysłowy sposób, aby nakarmić córkę. Podobne zadania wykonywał tata.

$\mathrm{Na}$ tym etapie pacjentka identyfikowała się z zimną emocjonalnie, nadmiernie ambitną babcią, stymulującą do nieustannej pracy lub nauki oraz zakazującą odpoczynku czy przyjemności, rozumianych jako zwykłe lenistwo i przejaw słabości. Starania matki, jej troskę o zdrowie i samopoczucie córki lekceważyły zarówno babcia, jak i pacjentka. Podejmowane przez matkę działania uważały za przesadzone - pomimo ewidentnie niskiej masy ciała pacjentki i głębokiego nasilenia depresji. Jednocześnie u pacjentki pojawiły się wspomnienia z podróży do Indii, gdzie gościła u tradycyjnej hinduskiej rodziny, która żyła ze sobą blisko emocjonalnie, chętnie spędzała wspólnie wolny czas, a posiłki były tego integralną częścią. Kobieta opowiadała, że „wszystko [jej] tam smakowało", przybrała nawet na wadze. Nasilone problemy z odżywianiem i depresja pojawiły się po powrocie do domu; dodatkowo wzmocniła je śmierć siostry babci, którą pacjentka szczególnie mocno przeżyła. Zaczęłyśmy tworzyć genogram rodziny pacjentki, skupiając się szczególnie na klanie od strony matki, z którym 
Unfortunately, they were unsuccessful. The grandmother and her husband, who abused her mentally and physically, had nine children: seven girls and two boys. During the war, the family survived ethnic cleansing when neighbours became fierce enemies, mercilessly murdering both adults and children only because they were Poles. During one of these massacres, the great grandfather and other men went to fight the assailants. The great grandmother, her children and other women from the neighbourhood were hiding in a specially prepared hideout. The youngest child, still an infant, was left alone in the fields so as not to reveal the hideout with its crying, thus condemning the remaining community members to certain death. During repatriation, one of the teenage daughters got lost and had to find her family in Poland on her own. When it turned out that she had been brutally raped and was pregnant, she was forced to leave home so as not to "bring shame upon the family." She had to manage on her own since then. She gave birth to a boy who exhibited paedophile tendencies as a young man. However, his actions were concealed, even when he abused his own cousin. All aunts were also silent about this so as not to "hurt their sister." Moreover, the oldest sister, who was considered the prettiest, had no children of her own. She maltreated both her husband and the youngest sister who had once been abandoned by her mother as an infant and later entrusted to her eldest sister to care for. Yet another sister glorified her violent father. Despite being hurt so much by her father, he wrote poems full of love about him. She entered into a relationship with a man who was equally aggressive towards her.

The patient's grandmother achieved higher education along with high professional and social status. Caring about accomplishments was the most important thing to her. She "trained" her daughter, and her husband was subordinate. He declaimed hateful and racists tirades towards the child. The patient's mother chose an emotionally immature partner whom she hoped to "teach love." As a child, she was brought up in a very strict way, with only commands and bans. She decided to raise her children in a different way: she gave them - especially the patient - almost complete freedom. She allowed them to experience by themselves what is good and bad for them. Another difficulty, which additionally affected her relationships with the patient, was a postnatal infection that forced her to stay in hospital longer. During this time, the child was taken care of by the grandmother and the father.

In the patient's recollections about the relationship with her mother, considerable ambivalence drew attention. On the one hand, she expressed respect and admiration for her mother, for her education, professional accomplishments, financial independence and efforts made to improve their reciprocal relationships. On the other hand, she felt angry and disappointed because the mother was unable to build the mother-daughter relationship, was helpless about her daughter's frustration and because she would ask what she, as the mother, should do when the patient pacjentka się identyfikowała. Rodzina pochodzi z terenów dzisiejszej Ukrainy. Praprababcia była kobietą zaradną, rządzącą w swoim domu. $Z$ niejasnych przyczyn, być może majątkowych, nie zważając na sprzeciw męża i synów, postanowiła wydać swoją jedyną córkę za człowieka gwałtownego i niezrównoważonego. Bracia starali się odwieść zalotnika od jego zamiarów, wmawiając mu, że siostra jest osobą kaleką, niewidomą - byleby tylko ustrzec ją przed tym małżeństwem. Niestety intryga się nie powiodła. Ze stosującym przemoc psychiczną i fizyczną mężem prababcia miała dziewięcioro dzieci: siedem dziewczynek i dwóch chłopców. Podczas wojny rodzina przeżyła czystki etniczne, $\mathrm{w}$ trakcie których dotychczasowi sąsiedzi stawali się zagorzałymi wrogami, mordującymi bez litości i dorosłych, i dzieci - tylko dlatego, że byli Polakami. W czasie jednej z tego typu masakr pradziadek razem $z$ innymi mężczyznami poszedł walczyć z napastnikami. Prababcia wraz z dziećmi i sąsiadkami ukrywała się w specjalnie przygotowanej kryjówce. Najmłodsze dziecko, jeszcze niemowlę, zmuszona była pozostawić samo, na polu, aby swoim płaczem nie zdradziło schronienia i tym samym nie skazało na pewną śmierć pozostałych członków społeczności. Podczas repatriacji jedna z nastoletnich córek zagubiła się i samodzielnie musiała odnaleźć rodzinę w Polsce. Gdy okazało się, że została brutalnie zgwałcona i jest w ciąży, została zmuszona do opuszczenia domu, po to, by „nie przynosić wstydu rodzinie”. Od tamtej pory musiała sobie radzić sama. Urodziła chłopca, który jako młody mężczyzna wykazywał skłonności pedofilskie. Jednak jego poczynania ukrywano - nawet wówczas, gdy molestował swego kuzyna. Wszystkie ciocie także zachowały milczenie na ten temat, aby „nie krzywdzić siostry”. Z kolei najstarsza siostra, uważana za najładniejszą, nie miała własnych dzieci. Źle traktowała swego męża, podobnie jak oddaną jej na wychowanie najmłodszą siostrę, już raz porzuconą w niemowlęctwie przez matkę. Kolejna siostra gloryfikowała swego przemocowego ojca. Mimo doznanych od niego wielu krzywd pisała o nim pełne miłości wiersze. Związała się z podobnie agresywnym w stosunku do niej mężczyzną. Babcia pacjentki zdobyła wyższe wykształcenie, pozycję zawodową i społeczną; dbanie o te osiągnięcia było dla niej najważniejsze. Swoją córkę „tresowała”, a mąż był jej podporządkowany. Wobec dziecka wygłaszał tyrady pełne nienawiści rasowej. Matka pacjentki wybrała sobie emocjonalnie niedojrzałego partnera, którego miała nadzieję „nauczyć miłości”. Sama w dzieciństwie traktowana była niezwykle surowo, doświadczała jedynie nakazów i zakazów. Swoje dzieci postanowiła więc wychowywać inaczej - dała im, a zwłaszcza pacjentce, niemal całkowitą wolność. Pozwalała na to, aby same doświadczały, co dla nich dobre, a co nie. Dodatkową trudnością, która znacząco wpłynęła na jej relację z pacjentką, była infekcja poporodowa, wymagająca dłuższej hospitalizacji matki. W tym czasie dziecko znajdowało się pod opieką babci i taty.

$\mathrm{W}$ opowieściach pacjentki dotyczących relacji z mamą zwracała uwagę duża ambiwalencja. $Z$ jednej strony kobieta wyrażała szacunek i podziw dla mamy za jej wykształcenie, 
could not cope with her emotions. "I have always felt more like my mum's friend than child." Abrupt behaviours and anger outbursts, which the patient overtly expressed as a child and which frightened adults so much, turned to autoaggression. Despite the lack of full predisposition, the patient was accepted at a ballet school thanks to her immense effort. Rigorous training and discipline as well as punishments inflicted by teachers helped somewhat harness her aggression. In her current comments, the patient notes that her main goal at that time was pain that she experienced and overcame by practicing even more despite suffering and injuries. In the environment of a ballet school, this behaviour was interpreted as an advantage, as an expression of proper motivation and strength of a dancer; and so was food restriction and weight loss. When observing her daughter's suffering and worsening somatic condition, the mother removed her from this school after a year. Until recently, the patient had a negative attitude to this decision and resented being "too weak" because other girls "managed to do it" and became ballet dancers. Actually, since that moment, both the mother and the patient have been seeking therapeutic help.

The history of traumatic events experienced by the women from the patient's family reaches three generations back. Mental, physical and sexual abuse, enslavement, threat to life and health, particularly during ethnic cleansing in Ukraine, were combined with forced silence and forbidden expression and experience of feelings. The facade of the family had to be impeccable. Discipline and work prevailed as an expression of strength and good assimilation. Showing feelings was prohibited and interpreted as weakness. This attitude helped the grandmother survive, grow up, get education and become financially independent. Meanwhile, the behaviour of the mother, her insights, reflections and a different form of communication created vibes in which the emotional sphere could exist. The patient belonged to a family generation that could recreate its dramatic history. This helped combine the cold intellectual message, expressed with the words "this had to be that way at that time," with profound feelings, surely experienced by physically and emotionally harmed women. Laura is now able to name and experience feelings because her ancestors survived, preserved the continuity of the family and gave her a safe space and approval for accepting help.

It seems that the greatest problem is the search for closeness with another person, which is perceived in an ambivalent way: on the one hand, it is something perfect, wonderful, as in the symbiotic original bond where two people seem to be one, and on the other hand, it is something very perilous, threatening the autonomy and even condemning for inevitable suffering associated with losing this close person. The grandmother and mother showed that a woman may be strong and independent of a man, she can count on herself and decide about her own life. However, neither of them built a relationship based on love and trust. The patient expresses rather negative feelings about men. She does not think of them as attractive partners. osiągnięcia zawodowe, niezależność finansową, za starania o poprawę ich wzajemnych stosunków. Z drugiej odczuwała złość i rozczarowanie z powodu tego, że rodzicielka nie potrafiła zbudować relacji matczynej z córką, że była bezradna wobec jej frustracji, że pytała dziecko, co jako matka powinna zrobić, gdy ono nie radzi sobie ze swoimi emocjami. „Zawsze czułam się bardziej koleżanką mamy niż jej dzieckiem”. Zachowania gwałtowne i impulsy złości, które pacjentka otwarcie wyrażała jako dziecko i które tak przerażały dorosłych w jej otoczeniu, przekształciły się następnie w autoagresję. Mimo braku pełnych predyspozycji, dzięki ogromnemu własnemu wysiłkowi zakwalifikowała się do szkoły baletowej. Panujący tam rygor i żelazna dyscyplina oraz stosowane przez nauczycieli kary pozwoliły na pewne okiełznanie jej agresji. W aktualnie wygłaszanych komentarzach pacjentka zauważa, że jej celem w tamtym okresie był ból, który odczuwała i pokonywała, ćwicząc jeszcze więcej pomimo cierpienia i kontuzji. W środowisku szkoły baletowej takie postępowanie było postrzegane jako zaleta, wyraz właściwej motywacji i siły tancerki, podobnie jak ograniczanie przyjmowania posiłków i utrata masy ciała. Mama, obserwując cierpienia córki i jej pogarszający się stan somatyczny, po roku zabrała ją z tej szkoły. Do niedawna pacjentka miała do tej decyzji negatywny stosunek, a do samej siebie żal, że okazała się „za słaba”, ponieważ inne dziewczynki „dały radę” i zostały baletnicami. Właściwie od tamtej pory i mama, i pacjentka poszukiwały dla siebie pomocy terapeutycznej.

Historia traumatycznych wydarzeń, których doświadczyły kobiety $\mathrm{z}$ rodziny pacjentki, sięga trzech pokoleń wstecz. Przemoc psychiczna, fizyczna, seksualna, zniewolenie, zagrożenie zdrowia i życia, zwłaszcza podczas czystek etnicznych na Ukrainie, połączone były $z$ nakazem milczenia oraz zakazem przeżywania i okazywania uczuć. Fasadowo rodzina musiała prezentować się nienagannie. Obowiązywały dyscyplina i praca - jako wyraz siły i dobrego przystosowania. Ujawnianie uczuć było zakazane i nazywane słabością. Taka postawa pozwoliła babci przeżyć, dorosnąć, zdobyć wykształcenie i niezależność finansową. Tymczasem zachowanie mamy, jej spostrzeżenia, przemyślenia, inny rodzaj komunikacji stworzyły klimat, w którym sfera emocji mogła już zaistnieć. Pacjentka przynależała więc do tego pokolenia w rodzinie, które mogło sobie pozwolić na odtworzenie dramatycznej historii. Dzięki temu udało się połączyć chłodny przekaz intelektualny - wyrażany słowami „tak musiało w tych czasach być” - z głębokimi uczuciami, których z pewnością doświadczały krzywdzone fizycznie i emocjonalnie kobiety. Laura może teraz nazywać uczucia i je przeżywać - bo jej poprzedniczki przetrwały, pozwoliły zachować ciągłość rodu, dały jej bezpieczną przestrzeń oraz przyzwolenie na przyjęcie pomocy.

Wydaje się, że nadal największy problem stanowi poszukiwanie bliskości w relacji z drugą osobą, która postrzegana jest ambiwalentnie: $\mathrm{z}$ jednej strony jako coś wymarzonego, cudownego, jak w czasach symbiotycznej więzi pierwotnej, gdzie dwoje wydaje się jednością, a z drugiej jako coś 
She thinks that a relationship with a woman is more appealing even though she had entered into both hetero- and homosexual relationships, in which she was a victim of mental abuse. It seems that this is another, currently important, subject for therapeutic work.

\section{CONCLUSION}

The article discussed the process of psychotherapy (concluded in an integrative mode, once a week for two years) in a patient who was allowed to seek specialist help only after the occurrence of severe clinical symptoms defined by a professional diagnosis (AS, anorexia nervosa, depression). During the therapy, the patient occurred to be strong enough to recreate the traumatic history of her family (mostly concerning ethnic cleansing in the Polish Eastern Borderlands and repatriation) and lead to the combination of cold intellectual message with profound emotional experiences. The transgenerational theory, described by Boszormenyi-Nagy, Bowen, Stierlin and McGoldrick, explain the ways which families use to uphold the memory of harm and merit in the next generations (Namysłowska, 2017). Systemic therapy, especially the work with a genogram, helps analyse transgenerational messages, understand mechanisms that govern a family, free their members from their secret burden and dramas, and abreact emotionally. This offers them a chance for recovery.

In Laura's system, there was no room for emotional experiences as this was considered a weakness. Only the manifestation of severe, life-threatening concomitant psychiatric disorders did free her from strict loyalty to transgenerational messages, and enabled the family to take care of the patient without a feeling of threat to the functioning system. In the case described above, the coexistence of both mechanisms, i.e. neurobiological causes and disturbed relations resulting from trauma inheritance, cannot be excluded completely. Nevertheless, psychotherapy helped significantly improve Laura’s well-being and functioning.

\section{Conflict of interest}

The author does not report any financial or personal links to other persons or organisations that might negatively affect the content of this publication and/or claim rights thereto. bardzo niebezpiecznego, zagrażającego autonomii i narażającego - czy nawet z góry skazującego - na nieuchronne cierpienie związane z utratą bliskiej osoby. Babcia i mama pokazały, że kobieta może być silna i niezależna od mężczyzny, może polegać na sobie i kierować swoim życiem tak, jak sama zdecyduje. Obie jednak nie zbudowały ze swoimi partnerami relacji opartej na miłości i zaufaniu. Pacjentka wyraża raczej negatywne opinie na temat mężczyzn, nie postrzega ich jako atrakcyjnych dla siebie partnerów. Uważa, że związek z kobietą jest dla niej bardziej pociągający, choć nawiązywała zarówno hetero-, jak i homoseksualne relacje, $w$ których była ofiarą przemocy psychicznej. Wydaje się, że jest to kolejny aktualnie ważny obszar do pracy terapeutycznej.

\section{PODSUMOWANIE}

Praca opisuje proces psychoterapii pacjentki (prowadzonej w nurcie integrującym, raz w tygodniu, przez dwa lata), która dopiero poprzez pojawienie się ciężkich objawów klinicznych, zdefiniowanych złożoną diagnozą lekarską (ZA, jadłowstręt psychiczny, depresja), zdołała uzyskać przyzwolenie na poszukiwanie specjalistycznej pomocy. Podczas pracy terapeutycznej okazała się osobą na tyle silną, żeby pozwolić sobie na odtworzenie traumatycznych historii rodzinnych (dotyczących zwłaszcza czystek etnicznych na Kresach Wschodnich i repatriacji) oraz doprowadzić do połączenia chłodnego przekazu intelektualnego z głębokimi przeżyciami emocjonalnymi. Teorie transgeneracyjne, które opisali Boszormenyi-Nagy, Bowen, Stierlin i McGoldrick, wyjaśniają sposoby, których używają rodziny, aby pamięć krzywd i zasług nie ginęła w następnych pokoleniach (Namysłowska, 2017). Terapia systemowa, a zwłaszcza praca nad genogramem, pozwala na analizę przekazów transgeneracyjnych, zrozumienie mechanizmów rządzących rodziną, uwolnienie jej członków od ciążących na nich tajemnic i dramatów oraz odreagowanie emocjonalne. Tym samym daje szansę na wyzdrowienie.

W systemie Laury nie istniało przyzwolenie na przeżywanie emocjonalne - odbierane ono było bowiem jako niebezpieczna słabość. Dopiero manifestacja ciężkich, zagrażających życiu współwystępujących zaburzeń psychicznych uwolniła ją od ścisłej lojalności wobec przekazów międzypokoleniowych, a rodzinie pozwoliła na zaopiekowanie się pacjentką, bez poczucia zagrożenia dla funkcjonowania systemu. W opisywanym przypadku nie można w sposób oczywisty wykluczyć współwystępowania obydwu mechanizmów - podłoża neurobiologicznego oraz zaburzeń w relacjach wynikających z dziedziczenia traumy. Niemniej jednak psychoterapia pozwoliła w znaczący sposób poprawić samopoczucie i funkcjonowanie Laury.

\section{Konflikt interesów}

Autorka nie zgłasza żadnych finansowych ani osobistych powiązań $z$ innymi osobami lub organizacjami, które mogtyby negatywnie wplynąc na treść publikacji oraz rościć sobie prawo do tej publikacji. 


\section{References / Piśmiennictwo}

American Psychiatric Association, 2010, DSM-5: The Future of Psychiatric Diagnosis. (n.d.). Proposed Draft Revisions to DSM Disorders and Criteria. Available from: http://www.dsm5.org/Pages/Default. aspx [cited: 20 April 2010].

Baron-Cohen S: Autism and Asperger Syndrome. Oxford University Press, New York 2008.

Baron-Cohen S: Is Asperger syndrome necessarily viewed as a disability? Focus Autism Other Dev Disabl 2002; 17: 186-191.

Koch SV, Larsen JT, Mouridsen SE et al.: Autism spectrum disorder in individuals with anorexia nervosa and in their first- and seconddegree relatives: Danish nationwide register-based cohort-study. Br J Psychiatry 2015; 206: 401-407.

Łucka I, Nowak P: Włosy babci - trauma transgeneracyjna. Psychiatr Psychol Klin 2014; 14: 89-94.
Namysłowska I: Czy przekaz transgeneracyjny może dotyczyć agresji? In: Piasecka B (ed.): Agresja - perspektywa psychoterapeutów. Wydawnictwo Uniwersytetu Jagiellońskiego, Kraków 2017: 95-107. Orwid M: Trauma. Wydawnictwo Literackie, Kraków 2009.

Prot K, Biedka $Ł$, Szwajca K et al.: Psychoterapia grupowa ocalałych z Holocaustu - doświadczenia własne. Psychoterapia 2010; 1 (152): 25-35.

Pudlo R, Pudlo M, Matysiakiewicz J et al.: Przebieg PTSD u osób deportowanych w dzieciństwie do ZSRR. Postępy Psychiatr Neurol 2005; 14 (supl. 1/20): 1-3.

Treasure J: Coherence and other autistic spectrum traits and eating disorders: building from mechanism to treatment. The Birgit Olsson lecture. Nord J Psychiatry 2013; 67: 38-42.

Wasilewska M: Parentification as a result of transgenerational trauma legacy. In: Kubacka-Jasiecka D, Kuleta M (eds.): Reflection on Psychological Mechanisms of Trauma and Posttraumatic Development. Wydawnictwo Kontekst, Kraków 2012: 39-53. 